\title{
Tumefactive demyelinating lesion
}

Figure MRI


T2-weighted axial section (A) and T1-weighted post gadolinium contrast sagittal (B) and coronal (C) sections display characteristic features of a tumefactive plaque including a T2-hypointense rim $^{1}$ and an open-ring pattern of contrast enhancement. ${ }^{2}$ Fluid attenuated inversion recovery coronal section (D) shows the additional white matter lesions in the left temporal lobe and pons supporting the diagnosis of multiple sclerosis.

A previously healthy 31-year-old woman presented with a 2-week history of progressive left hemiparesis. MRI (figure) demonstrated a $3 \mathrm{~cm}$ enhancing mass in the right posterior frontal white matter with several smaller lesions in the white matter of the contralateral hemisphere and brainstem (figure, D). A stereotactic biopsy of the large lesion was performed to establish the diagnosis. This showed no evidence of neoplasia but revealed demyelinated neurones with axonal sparing and an infiltrate of foamy macrophages and perivascular lymphocytes - typical histological features of a multiple sclerosis plaque. The patient was treated with corticosteroids and her symptoms rapidly improved.

Mathew R. Guilfoyle, MB BCh, and Ramez W. Kirollos, MD, Cambridge, UK

Disclosure: The authors report no conflicts of interest.

Address correspondence and reprint requests to Dr. Mathew R. Guilfoyle, Addenbrooke's Hospital, Hills Road, Cambridge, UK CB2 2QQ; mrguilfoyle@gmail.com

\section{REFERENCES}

1. Schwartz KM, Erickson BJ, Lucchinetti C. Pattern of T2 hypointensity associated with ring-enhancing brain lesions can help to differentiate pathology. Neuroradiology 2006;48:143-149.

2. Given CA 2nd, Stevens BS, Lee C. The MRI appearance of tumefactive demyelinating lesions. AJR Am J Roentgenol 2004; 182:195-199. 


\section{Neurology}

Tumefactive demyelinating lesion

Mathew R. Guilfoyle and Ramez W. Kirollos

Neurology 2007;68;2155

DOI 10.1212/01.wnl.0000265516.19499.77

This information is current as of June 11, 2007

\section{Updated Information \&} Services

References

Permissions \& Licensing

Reprints including high resolution figures, can be found at: http://n.neurology.org/content/68/24/2155.full

This article cites 2 articles, 0 of which you can access for free at: http://n.neurology.org/content/68/24/2155.full\#ref-list-1

Information about reproducing this article in parts (figures,tables) or in its entirety can be found online at:

http://www.neurology.org/about/about_the_journal\#permissions

Information about ordering reprints can be found online: http://n.neurology.org/subscribers/advertise

Neurology ${ }^{\circledR}$ is the official journal of the American Academy of Neurology. Published continuously since 1951, it is now a weekly with 48 issues per year. Copyright . All rights reserved. Print ISSN: 0028-3878. Online ISSN: 1526-632X.



